\title{
Molecular and Genomic Alterations in Glioblastoma Multiforme
}

\author{
Ines Crespo, ${ }^{*}$ Ana Louisa Vital, ${ }^{*}$ María Gonzalez-Tablas, ${ }^{\dagger}$ María del Carmen Patino, ${ }^{\ddagger}$ Alvaro Otero, ${ }^{\circledR \Phi}$ María Celeste Lopes, ${ }^{*}$ \\ Catarina de Oliveira, ${ }^{*}$ Patricia Domingues, ${ }^{* \top \pi}$ Alberto Orfao, ${ }^{+\top}$ and Maria Dolores Tabernero ${ }^{\dagger \uparrow \|}$
}

From the Centre for Neurosciences and Cell Biology, * Faculties of Pharmacy and Medicine, University of Coimbra, Coimbra, Portugal; the Department of Medicine, ${ }^{\dagger}$ Centre for Cancer Research (Centro de Investigación del Cáncer-Instituto de Biología Molecular y Celular del Cáncer; Centro Superior de Investigaciones Científicas/Universidad de Salamanca; Instituto de Investigación Biomédica de Salamanca), and the Department of Statistics, ${ }^{\ddagger}$ University of Salamanca, Salamanca, Spain; the Neurosurgery Service ${ }^{\S}$ and the Institute of Health Science Studies of Castilla and León Research Laboratory, University Hospital of Salamanca, Salamanca, Spain; and the Biomedical Research Institute of Salamanca, "Salamanca, Spain

\author{
Accepted for publication \\ February 9, 2015. \\ Address correspondence to \\ Maria Dolores Tabernero, \\ M.D., Ph.D., Research Labora- \\ tory, University Hospital of \\ Salamanca, Paseo San Vicente \\ 58-182, Salamanca, Spain. \\ E-mail: taberner@usal.es.
}

\begin{abstract}
In recent years, important advances have been achieved in the understanding of the molecular biology of glioblastoma multiforme (GBM); thus, complex genetic alterations and genomic profiles, which recurrently involve multiple signaling pathways, have been defined, leading to the first molecular/genetic classification of the disease. In this regard, different genetic alterations and genetic pathways appear to distinguish primary (eg, EGFR amplification) versus secondary (eg, IDH1/2 or TP53 mutation) GBM. Such genetic alterations target distinct combinations of the growth factor receptor-ras signaling pathways, as well as the phosphatidylinositol 3-kinase/phosphatase and tensin homolog/AKT, retinoblastoma/cyclindependent kinase (CDK) N2A-p16 ${ }^{\text {INK4A }}$, and TP53/mouse double minute (MDM) 2/MDM4/CDKN2A-p14 ${ }^{\text {ARF }}$ pathways, in cells that present features associated with key stages of normal neurogenesis and (normal) central nervous system cell types. This translates into well-defined genomic profiles that have been recently classified by The Cancer Genome Atlas Consortium into four subtypes: classic, mesenchymal, proneural, and neural GBM. Herein, we review the most relevant genetic alterations of primary versus secondary GBM, the specific signaling pathways involved, and the overall genomic profile of this genetically heterogeneous group of malignant tumors. (Am J Pathol 2015, 185: 1820-1833; http://dx.doi.org/ 10.1016/j.ajpath.2015.02.023)
\end{abstract}

Glioblastoma multiforme (GBM) is a World Health Organization grade IV astrocytoma, which represents the most common and aggressive primary brain tumor. Most GBMs are primary tumors that arise de novo as aggressive, highly invasive neoplasias, usually in the absence of clinical, radiological, or histopathological evidence of prior disease and precedent lower-grade lesions; thus, approximately two-thirds of patients with primary GBM have a clinical history of $<3$ months, ${ }^{1,2}$ with rapid development of clinical symptoms. By contrast, secondary GBMs are much less common and they derive from the transformation/progression of lower-grade astrocytomas. ${ }^{1}$ Interestingly, these two subtypes of glioblastoma also affect patients at different ages: primary GBM is more common in older patients, whereas secondary GBM tends to occur among patients $<45$ years. Primary and secondary GBMs are usually indistinguishable on histological grounds, but they show clearly different genetic alterations and genomic profiles (Table 1), supporting the notion that the two groups of GBM arise through different genetic pathways. ${ }^{23}$ Herein, we review current knowledge about the signaling pathways most commonly involved in GBM, the molecular and genetic alterations of primary and secondary GBM, including the clinical impact of such alterations, and the most relevant gene expression profiling subgroups of these tumors.

\footnotetext{
Supported in part by FCT (Portuguese National Funding Agency for Science, Research and Technology) grant SFRH/BD/64799/2009 (P.D.) and by IECSCYL (Fundación Instituto de Estudios Ciencias de la Salud de Castilla y León; Soria, Spain) (M.D.T.) and GRS909A14.

Disclosures: None declared.
} 
Table 1 Epigenetic and Genetic Alterations as Well as Gene/Protein Expression Profiles Typically Found in Primary versus Secondary Glioblastomas

\begin{tabular}{|c|c|c|c|}
\hline Variable & Primary glioblastoma, \% (95\%) & Secondary glioblastoma, \% (5\%) & Reference \\
\hline \multicolumn{4}{|l|}{ Promoter methylation } \\
\hline MGMT & 36 & 75 & 3 \\
\hline TIMP-3 & 28 & 71 & 4 \\
\hline CDKN2A-p14 $4^{A R F}$ & 6 & 31 & 6 \\
\hline CDKN2A-p16 $6^{I N K 4 a}$ & 3 & 19 & 6 \\
\hline \multicolumn{4}{|l|}{ Genetic alterations } \\
\hline EGFR amplification & $36-60$ & 8 & 1 \\
\hline TERT mutation & 58 & 28 & 1,10 \\
\hline CDKN2A-p16 ${ }^{I N K 4 a}$ deletion & $31-78$ & 19 & 1 \\
\hline TP53 mutation & 28 & 65 & 1 \\
\hline PTEN mutation & 25 & 4 & 1 \\
\hline $\mathrm{LOH} 13 q$ & 12 & 38 & 11 \\
\hline $\mathrm{LOH} 19 \mathrm{q}$ & 6 & 54 & 11 \\
\hline \multicolumn{4}{|l|}{ Gene/protein expression profiles } \\
\hline Fas (AP0-1; CD95)* & 100 & 21 & 12 \\
\hline Survivin* & 83 & 46 & 13 \\
\hline MMP-9* & 69 & 14 & 14 \\
\hline $\mathrm{EGFR}^{*}$ & 63 & 10 & 15 \\
\hline $\mathrm{EGFR}^{\dagger}$ & High & Low & 16 \\
\hline MDM2* & 31 & 0 & 17 \\
\hline VEGF & High & Low & 18 \\
\hline VEGF fms-related tyrosine kinase $1^{\S}$ & High & Low & 19 \\
\hline $\mathrm{IGFBP}^{\S}$ & High & Low & 19 \\
\hline DUOX2 $2^{\dagger}$ & Low & High & 16 \\
\hline HNRPA3 $^{\dagger}$ & Low & High & 16 \\
\hline WNT-11 protein precursor ${ }^{\dagger}$ & Low & High & 16 \\
\hline Cadherin-related tumor-suppressor homolog precursor ${ }^{\dagger}$ & Low & High & 16 \\
\hline ADAMTS- $19^{\dagger}$ & Low & High & 16 \\
\hline
\end{tabular}

Modified from Ohgaki and Kleihues ${ }^{22}$ with permission from the American Society for Investigative Pathology.

*Immunohistochemistry.

†Two-dimensional protein gel electrophoresis.

"Enzyme-linked immunosorbent assay.

${ }^{\S} \mathrm{CDNA}$ array.

IRT-PCR.

ADAMTS-19, ADAM metallopeptidase with thrombospondin type 1 motif, 19; AP0-1, apoptosis-mediating cell membrane protein; ASCL1, achaete-scute complex-like 1; DUOX2, dual oxidase 2; EGFR, epidermal growth factor receptor; ERCC6, excision repair cross-complementation group 6; HNRPA3, heterogeneous nuclear ribonucleoprotein A3; IGFBP, insulin-like growth factor binding protein; LOH, loss of heterozygosity; MDM, mouse double minute; MMP, matrix metalloproteinases; PDGFR, platelet-derived growth factor receptor; TIMP, tissue inhibitor of metalloproteinases; VEGF, vascular endothelial growth factor; WNT-11, wingless-type MMTV integration site family, member 11.

\section{Oncogenic Pathways Involved in GBM}

The many different genetic and molecular alterations present in GBM lead to modifications of several major signaling pathways that result in brain tumor growth and progres$\operatorname{sion}^{24,25}$ (Figure 1A). Although the involvement of several well-known pathways in gliomagenesis is indubitable, there are complex interactions among them, including interactions 
A

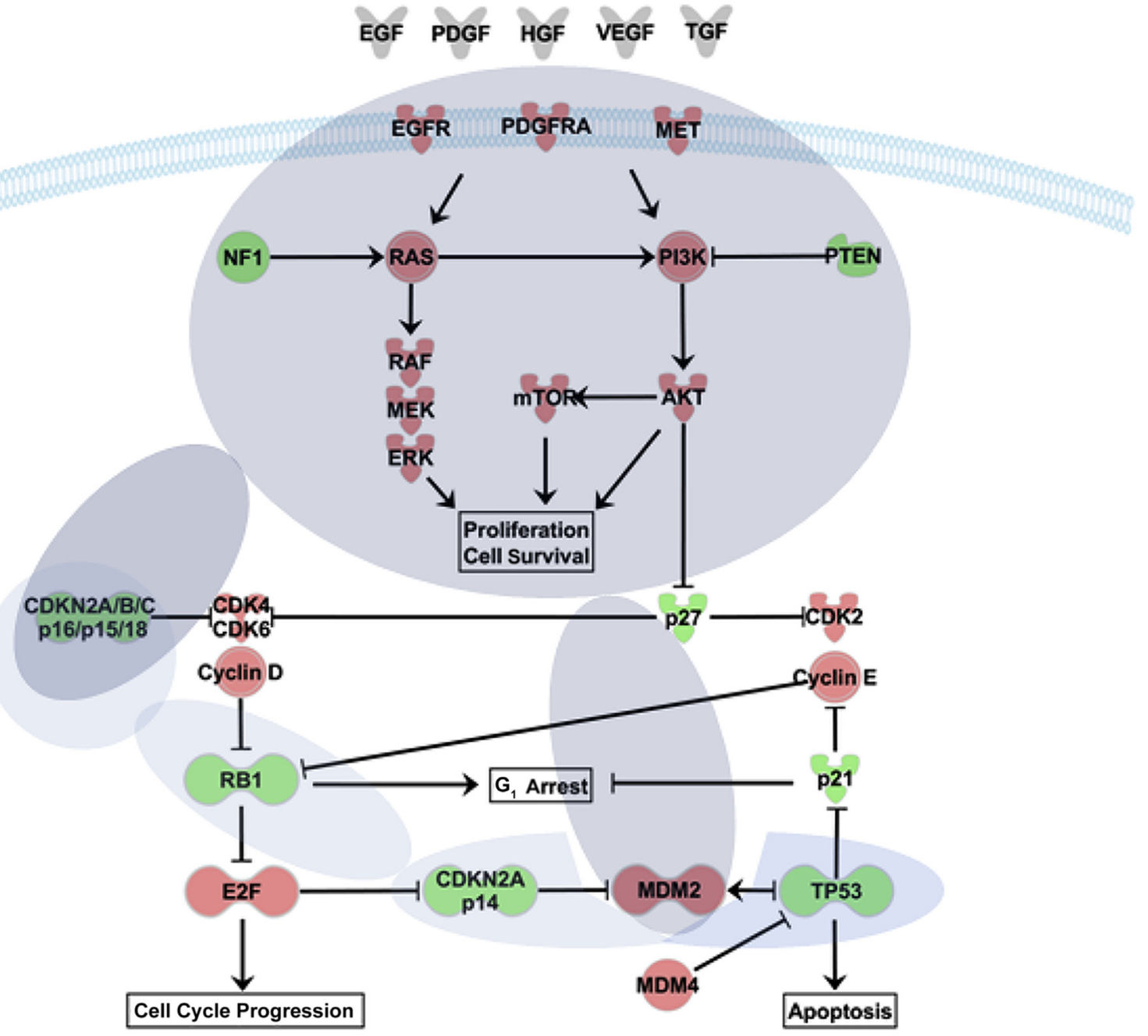

B

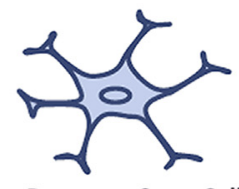

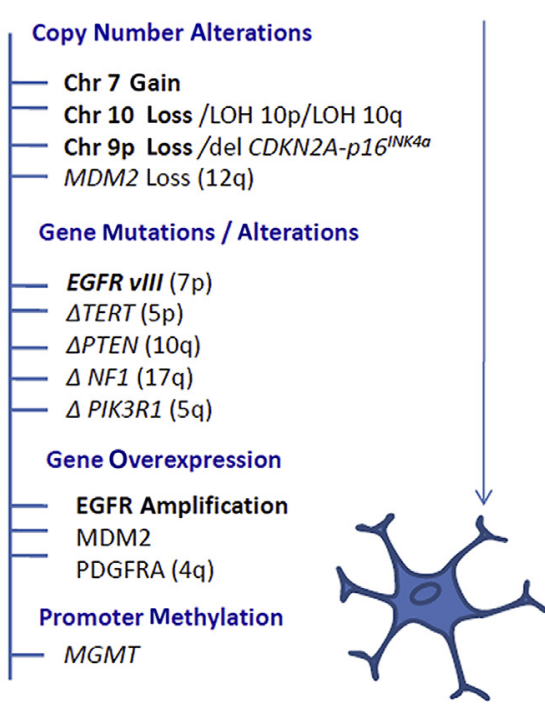

WHO Grade IV, Primary Glioblastoma

Precursor Stem Cells

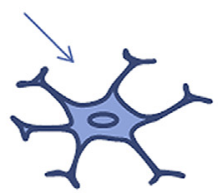

WHO Grade II, Diffuse Astrocytoma

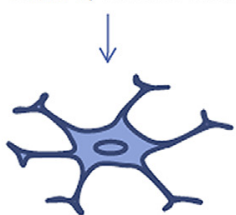

WHO Grade III, Anaplastic Astrocytoma

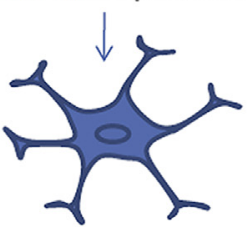

WHO Grade IV, Secondary Glioblastoma 
with additional unknown players, which potentially contribute to the initiation and transformation of GBM. ${ }^{26}$ The most relevant signaling pathways involved in GBM include, among others, growth factor tyrosine kinase receptor (TKR)-triggered pathways, including the Ras sarcoma (Ras) pathway, as well as the phosphatidylinositol 3-kinase (PI3K)/ phosphatase and tensin homolog (PTEN)/AKT, retinoblastoma (RB)/cyclin-dependent kinase $(C D K) N 2 A-p 16^{I N K 4 a}$, and the TP53/mouse double minute 2 (MDM2)/MDM 4/ CDKN2A-p14 ${ }^{\text {ARF }}$ pathways.

\section{Growth Factor TKR Pathways}

Both the platelet-derived growth factor (PDGF) and epidermal growth factor (EGF) play an important role in normal and tumoral gliogenesis, through activation of complex intracellular cascades modulated by G-protein-coupled receptors and second messengers that converge at multiple sites. Overexpression of PDGF and EGF receptor (EGFR) in GBM suggests that these TKR-signaling pathways are critical targets in gliomagenesis. ${ }^{27}$

The PDGF family consists of four different ligands (PDGF-A, PDGF-B, PDGF-C, and PDGF-D) that signal through the PDGF receptor (PDGFR) $\alpha$ and PDGFR $\beta .{ }^{28}$ Both the PDGF ligands and receptors are often co-expressed in glioma cell lines and primary GBM tissues, suggesting the establishment of both autocrine and paracrine signaling loops, which may contribute to tumor formation and progression. PDGFRA and PDGFA are expressed in tumor cells, whereas PDGFB and PDGFRB have been typically found in glioma-associated endothelial cells. Studies on the two new PDGFR ligands PDGFC and PDGFD indicate that they may also play a role in the development of brain tumors. Because co-expression of PDGF and PDGFR has been observed in astrocytomas of all grades, PDGF autocrine signaling may be considered as an early event, with additional secondary alterations in cell signaling being potentially required for progression to GBM. A subset of gliomas characterized by dysregulated PDGFR activity (due to amplification and rearrangement of the PDGFRA gene locus and/or overexpression of the PDGF ligand) has been described, ${ }^{29}$ and characterized by The Cancer Genome Atlas (TCGA; see below). ${ }^{21}$ Interestingly, studies performed on different in vivo animal models have shown that PDGFA stimulates the proliferation of PDGFRA-positive neural stem cells residing in the subventricular zone of the adult murine brain, which are able to differentiate and generate glioma-like lesions, ${ }^{30}$ suggesting a susceptibility of adult neural stem cells to oncogenic transformation by PDGFRA alteration.

EGFR and its ligands are variably expressed throughout the brain development from embryogenesis into adulthood, suggesting a critical role of EGFR signaling in the proliferation, migration, differentiation, and survival of all types of central nervous system cells and their precursors. ${ }^{31}$ In GBM cells, EGFR signaling may be activated in a ligand dependent or independent way, through overexpression of both the ligand(s) and the receptor, leading to an autocrine loop, and via genomic amplification of $E G F R$ and/or mutation of the receptor, leading to constitutive activation in the absence of ligand ${ }^{32}$; both types of alterations may coexist in individual GBM. The oncogenic properties of EGFR are associated with a constitutive and uncontrolled increase in its phosphorylation (catalytic) activity. EGFR gene mutations/rearrangements and expression of their aberrant protein products are frequently observed in GBM so far; seven common variants have been identified, from which variant 3 (EGFRvIII or del2-7 EGFR, $\triangle$ EGFR), which lacks a sequence of 267 amino acids in the extracellular ligandbinding domain leading to a constitutively activated EGFR and pathway, is the most frequent one (it is present in 20\% to $50 \%$ of GBMs that carry EGFR amplification). The introduction of this truncated receptor into glioma cells dramatically enhances their tumorigenicity in vivo through both increased cellular proliferation and reduced apoptosis. ${ }^{33}$

Ligand-activated receptors trigger downstream signal transduction pathways, including the Ras/rapidly accelerated fibrosarcoma (Raf)/mitogen-activated protein kinase (MAPK) pathway, the PI3K/AKT pathway, the protein kinase C pathway, and the STAT pathway, together with vascular endothelial growth factor production, with an impact on cell proliferation, migration, invasion, resistance to apoptosis, and tumor neovascularization. ${ }^{34}$

\section{The Ras Pathway}

Ras is a guanosine-nucleotide-binding protein (G-protein), whose activation and deactivation is controlled by cycling

\footnotetext{
Figure 1 Schematic representation of the different genetic abnormalities and the major signaling pathways involved in the pathogenesis of human glioblastoma. A: The interactions between the major signaling pathways altered in primary glioblastoma multiforme (GBM; dark gray) and secondary GBM (light gray). Genes that are inactivated or hyperactivated by different mechanisms are shown in green and red, respectively. In the phosphatidylinositol 3kinase (PI3K)/phosphatase and tensin homolog (PTEN)/Akt signaling pathway, the growth factor receptor becomes activated and recruits PI3K to the cell membrane, converting phosphatidylinositol-4,5-bisphosphate to the PIP3 second messenger molecule. Downstream effector molecules, such as AKT and the mammalian target of rapamycin (mTOR), are then activated, which help to induce cell proliferation and block apoptosis. PTEN terminates the phosphatidylinositol 3,4,5-trisphosphate (PIP3) signal; inactivation leads to increased availability of PI3K, and PI3K activates AKT, which, in turn, leads to an increased proliferative activity and survival. In the TP53 pathway, TP53 mutation or increased degradation of TP53 because of increased mouse double minute (MDM) 2 activity interrupts the normal cell cycle arrest and apoptosis after DNA damage. In the retinoblastoma protein (RB) pathway, cyclin-dependent kinase (CDK) 4 and CDK6 form complexes with members of the cyclin D family and phosphorylate the RB, which releases the E2F transcription factor, inducing cell proliferation by transcription of genes that promote DNA synthesis. Loss of RB leads to elevated levels of E2F and, therefore, cell proliferation. B: The most frequent and relevant molecular abnormalities of primary versus secondary GBM are shown. Chr, chromosome; EGF, epidermal growth factor; EGFR, EGF receptor; ERK, extracellular signal-regulated kinase; HGF, hepatocyte growth factor; LOH, loss of heterozygosity; NF1, neurofibromatosis type I; PDGF, platelet-derived growth factor; PDGFR, PDGF receptor; TGF, transforming growth factor; VEGF, vascular endothelial growth factor; WH0, World Health Organization.
} 
between the active GTP-bound and inactive GDP-bound forms. Receptor-mediated activation of Ras and Ras activation by oncogenic mutations are common in human tumors and contribute to the development and maintenance of the malignant phenotype. For example, the active Ras-GTP protein, through its downstream effectors, including the Raf, PI3K, and Ral-guanine nucleotide exchange factors, promotes cell cycle progression, survival, and migration. ${ }^{35}$

An increased Ras pathway activity is observed in virtually all GBMs. ${ }^{36}$ Interestingly, $R A S$ mutations are rarely found in GBM. However, high levels of Ras-GTP have been documented in GBM cell lines and primary tumors, suggesting that this signaling pathway is activated by upstream factors, such as TKR activation (eg, EGFR or PDGFR), which might be required for tumor induction, progression, and maintenance. Ras-GTP is downstream of growth factor receptors at a major signal transduction crossroad, translating extrinsic messages into the Raf-kinase/MAPK/ extracellular signal-regulated kinase pathway, PI3K/AKT, or PI3K/Rac/Rho pathways, influencing cell proliferation, survival, and migration. In fact, MAPK/extracellular signalregulated kinase signaling, one of the downstream effectors of Ras, is also increased in human GBM. ${ }^{34}$ In GBM, the existence of mutations affecting the expression or the activity of MAPKs has not been reported. However, because MAPKs may contribute to cell proliferation and could be activated in response to the inhibition of $\mathrm{PI} 3 \mathrm{~K} /$ mammalian target of rapamycin, their role in gliomagenesis is currently under investigation. In addition, the Ras signaling pathway may also be activated through the loss of function of neurofibromatosis type I (NF1), a negative regulator of Ras. Germline and lossof-function NF1 mutations have been identified in neurofibromatosis type I, which includes GBM as part of the clinical spectrum. In this regard, the results of TCGA Consortium showed that approximately $20 \%$ of GBMs harbor loss-offunction mutations of the $N F 1$ gene. ${ }^{24}$

\section{The PI3K/PTEN/AKT Pathway}

Elevated signaling through the PI3K-mediated cell signaling pathway has been implicated in the pathogenesis of GBM. Recruitment of PI3K to the cell membrane activates downstream effector molecules, such as AKT and mammalian target of rapamycin, resulting in cell proliferation and increased cell survival by blocking apoptosis. ${ }^{37}$ The PTEN tumor-suppressor gene negatively regulates PI3K, but its function is frequently lost in GBM because of loss of heterozygosity $(\mathrm{LOH})$ at the $10 \mathrm{q} 23.3$ locus or because of gene mutations ( $15 \%$ to $40 \%$ ), ${ }^{38}$ causing constitutive activation of the PI3K pathway and higher levels of activated AKT in glioma cells. Some reports also indicate that PTEN plays a significant role in inducing $\mathrm{G}_{1}$ cell cycle arrest and apoptosis, along with regulation of cell differentiation. Tumors with an activated PTEN/AKT pathway may be sensitive to mammalian target of rapamycin inhibitors (eg, rapamycin). ${ }^{39}$ Several studies using viral vectors have shown that wild-type PTEN suppresses tumorigenicity of glioma cells and inhibits the PI3K/AKT pathway. ${ }^{40}$ Thus, the PI3K/PTEN/AKT pathway appears to play a role in gliomagenesis, as also supported by the findings of the pilot project of the TCGA, which identified alterations in the EGFR/Ras/NF1/PTEN/PI3K pathway in $88 \%$ of all GBM patients. ${ }^{24}$

\section{The RB/CDKN2A-p16 ${ }^{\text {INK4a }}$ Pathway}

This pathway plays a central role in the regulation of cell cycle and cell proliferation, because its components are activated and/or inhibited by growth-promoting as well as growth-suppressing signals. ${ }^{41}$ The RB gene (13q14) encodes the RB phosphoprotein; in quiescent cells, RB is in a hypophosphorylated state (active) bound to E2F, preventing transcription of genes important for mitosis and, thus, preventing progression through the $\mathrm{G}_{1} / \mathrm{S}$ cell cycle checkpoint. In proliferating cells, growth factors lead to the induction of cyclin D1, as well as to the activation of CDK2/cyclin E through degradation of its inhibitor, p2 $7^{\mathrm{Kip} 1}$. These activated CDK-cyclin complexes trigger phosphorylation of RB in late $\mathrm{G}_{1}$ phase, which is maintained later in the $S, G_{2}$, and $M$ phases. Phosphorylated (inactive) RB enables E2F release, leading to transcriptional activation of growth-promoting genes, required for DNA synthesis and cell growth. ${ }^{37} \mathrm{Nega}-$ tive regulators of the RB signaling pathway include the Ink4 family of proteins (CDKN2A-p16 ${ }^{\mathrm{INK} 4 \mathrm{a}}, \mathrm{CDKN} 2 \mathrm{~B}-\mathrm{p} 15^{\mathrm{INK} 4 \mathrm{~b}}$, CDKN2C-p18 ${ }^{\mathrm{INK} 4 \mathrm{c}}$, and CDKN2D-p19 ${ }^{\mathrm{INK} 4 \mathrm{~d}}$ ) that compete with the D-cyclins for CDK4/6, to prevent the formation of the active kinase complex that phosphorylates RB. ${ }^{41}$

Inactivation of the RB pathway through disrupted RBE2F interaction may occur by mutation of the $R B$ gene itself, by loss of $\mathrm{RB}$ expression, or by the inactivation of $\mathrm{RB}$ by phosphorylation through $\mathrm{CDK} /$ cyclin complexes. CDKs can be activated by an increase in the amount of the catalytic enzyme, by an increase in the amount of their cofactors (cyclins), and/or by a decrease in the amount of endogenous CDK inhibitors (eg, CDKN2A-p16 ${ }^{\mathrm{INK} 4 \mathrm{~A}}$ ). In addition, the CDKN2A genetic locus at chromosome 9p21 produces both CDKN2A-p14 ${ }^{\mathrm{ARF}}$ and CDKN2A-p16 ${ }^{\mathrm{INK} 4 \mathrm{a}}$ by alternative splicing. ${ }^{42}$ Because $\mathrm{p} 16^{\mathrm{INK} 4 \mathrm{a}}$ negatively regulates CDK4 and $\mathrm{p} 14^{\mathrm{ARF}}$ inhibits MDM2, leading to a rapid blockade of the ubiquitin-mediated decay of TP53, simultaneous inactivation of both genes by homozygous deletion dysregulates both the RB and the TP53 pathways. ${ }^{43}$

The RB pathway is altered in $78 \%$ of 206 primary GBMs, ${ }^{34}$ either directly by mutations, deletions, or promoter methylation at the $R B$ locus or indirectly through alterations on the $\mathrm{RB}$ positive and negative regulators. In turn, $R B$ promoter methylation and gene silencing are more frequently found in secondary (43\%) than in primary (14\%) GBMs. ${ }^{44}$ Alterations in the RB pathway include homozygous deletion and mutation of $C D K N 2 A-p 16^{I N K 4 a}$ and $R B$ in $52 \%$ and $11 \%$ of the samples, respectively, and homozygous deletion of $C D K N 2 B-p 15^{I N K 4 b}$ and $C D K N 2 C-p 18^{I N K 4 c}$ in $47 \%$ and $2 \%$ of the tumors, 
respectively. In turn, $C D K 4, C D K 6$, and $C C N D 2$ (cyclin D2) gene amplification has been found in $18 \%, 1 \%$, and $2 \%$ of GBMs, respectively. ${ }^{24}$ Activated AKT deregulates cell growth by stabilization of cyclin D and promotion of nuclear entry of MDM2, leading to degradation of TP53. AKT might also inhibit p21 expression through its phosphorylation and activation of MDM2. In addition, activated AKT exerts an anti-apoptotic activity by phosphorylating and inactivating pro-apoptotic signaling proteins (eg, BAD and caspase 9), and it may contribute to tumor invasion and metastasis by stimulating secretion of matrix metalloproteinases. ${ }^{45}$

\section{The TP53/MDM2/MDM4/CDKN2A-p14 ${ }^{\text {ARF }}$ Pathway}

The TP53 protein, coded by the TP53 gene at chromosome $17 \mathrm{p} 13.1$, plays a role in the cell cycle, cellular responses to DNA damage, cell death, and differentiation. It is a sequencespecific nuclear transcription factor that binds as a tetramer to defined consensus sites within the DNA, affecting the transcription of its target genes, by either transcriptional activation or modulation of the activation of other proteins through direct binding. ${ }^{43}$ The TP53 network is activated in response to cellular stress conditions and facilitates DNA repair or induces cell death in case of too much damage, preventing cells with mutated or damaged DNA from dividing. TP53 transcriptionally regulates the promoters of potential effector genes, such as p21, which blocks cell cycle progression at the $\mathrm{G}_{1}$ phase by binding and inhibiting the function of cyclin-D proteins. ${ }^{46}$ This gives time for DNA repair before replication or mitosis and, thereby, links p21 directly to the tumorsuppressor function of TP53. Moreover, the TP53 and the RB pathways interact with each other via $\mathrm{p} 21$.

Recent findings show that TP53 also regulates proliferation, differentiation, and survival of stem cells, further highlighting the relevance of TP53 in suppressing GBM. ${ }^{47}$ After stress, the activity of TP53 is blocked by its negative regulator MDM2, whose transcription is induced by TP53, generating a negative feedback loop that regulates the activity of TP53 and the expression of MDM2. ${ }^{43}$ In addition, activation of TP53 is achieved through inactivation of MDM2 by CDKN2A-p14 ${ }^{\text {ARF }}$ binding. The MDM4 TP53 binding protein homolog (also called MDMX) also regulates TP53 activity, and p14 ${ }^{\mathrm{ARF}}$ is negatively regulated by TP53.

The TP53 signaling pathway is disrupted in GBM due to TP53 mutation and/or amplification, overexpression of MDM2, and/or loss of expression of CDKN2A-p14 ${ }^{\mathrm{ARF}}$, all such alterations blocking TP53 activity and potentially leading to uncontrolled cell proliferation and tumor formation. In human gliomas, TP53 mutations are missense mutations and target the highly conserved domains of TP53 in exons 5, 7, and 8, which are crucial for DNA binding. At least one alteration in the TP53/MDM2/CDKN2A-p14 ${ }^{\mathrm{ARF}}$ pathway has been reported to occur in approximately $50 \%$ of primary glioblastomas and in $>70 \%$ of secondary glioblastomas. ${ }^{48}$ Consistently, the TCGA pilot project showed an overall frequency of genetic alterations in the TP53/ MDM2/MDM4/CDKN2A-p14 ${ }^{\mathrm{ARF}}$ pathway in glioblastomas of $87 \%$, with such alterations being associated with TP53 mutation or homozygous deletion in $35 \%$ of cases, MDM2 amplification in 14\%, MDM4 amplification in 7\%, and CDKN2A-p1 $4^{A R F}$ homozygous deletion or mutation in $49 \%$ of all GBM cases. ${ }^{24}$ Amplification of MDM4 was detected in 4\% of GBM with neither TP53 mutation nor MDM2 amplification. ${ }^{49}$

\section{Epigenetic Changes in GBM}

Gliomas present a variety of epigenetic alterations that induce changes in normal gene expression, without altering the DNA sequence. Aberrant epigenetic mechanisms, such as DNA methylation, histone modifications, chromatin remodeling, or altered noncoding RNA expression (eg, miRNAs), are currently recognized as relevant events in tumor formation, in addition to classic genetic alterations. ${ }^{50}$ Until now, most studies about the epigenetic changes of glioblastoma have focused on DNA methylation, including hypermethylation of $\mathrm{CpG}$ islands (associated with tumorsuppressor gene silencing), gene-specific hypomethylation (resulting in aberrant activation of oncogenes), and genomewide hypomethylation (potentially leading to chromosomal instability, loss of imprinting, and uncontrolled cell proliferation). ${ }^{51}$ To date, multiple changes in the DNA methylation pattern of promoters of genes involved in cell cycle regulation (eg, CDKN2A-p16 ${ }^{I N K 4 a}$ and $C D K N 2 B-p 15^{I N K 4 b}$ ), tumor suppression (eg, RB, VHL, EMP3, RASSF1A, and $B L U$ ), DNA repair, and genome integrity (eg, $M G M T$ and $h M L H 1$ ), as well as genes associated with regulation of tumor invasion and inhibition of apoptosis (eg, DAPKl, TIMP3, CDH1, PCDHGA11, and TMS1/ASC), ${ }^{5,52-55}$ have been reported in GBM.

\section{Genetic Alterations of Primary versus Secondary GBM}

Overall, primary GBMs typically harbor three predominant genetic alterations, as confirmed also by high-density singlenucleotide polymorphism arrays ${ }^{56}$ : amplification and/or a high rate of $E G F R$ mutation in chromosome 7p, homozygous deletion of the CDKN2A-p16 $6^{I N K 4 a}$ gene in chromosome $9 \mathrm{p}$ (with absence of the CDKN2A-p16 $6^{\mathrm{INK} 4 \mathrm{a}} \alpha$ and/or the CDKN2A-p14 ${ }^{\mathrm{ARF}} \beta$ transcripts), and deletion of the PTEN gene typically in association with monosomy $10 .{ }^{56-58}$ In addition, amplification of the $M D M 2$ oncogene is also present in a smaller, but significant, percentage of primary GBMs $(<15 \%)$, particularly among those primary glioblastomas that lack TP53 mutations and telomerase reverse transcriptase (TERT) promoter mutations ${ }^{59,60}$ (Figure 1B).

Amplification and/or mutation of the EGFR gene (7p11.2) occur in $36 \%$ to $60 \%$ of primary GBMs. The most common EGFR mutant type, variant 3 (EGFRvIII), is due to 
an 801-bp in-frame deletion of exons 2 to 7 , and it leads to a constitutively active protein, resulting in increased proliferation and survival of mutated cells. ${ }^{33}$ In most GBM tumors, overexpression of the EGFRvIII mutant coexists with $E G F R$ gene amplification, but overexpression of the EGFRvIII mutant without EGFR amplification has also been reported in a small proportion of primary GBMs. ${ }^{61}$ All primary glioblastomas with EGFR amplification show EGFR overexpression, and $70 \%$ to $90 \%$ of cases with EGFR overexpression have EGFR amplification.

Homozygous deletion of $C D K N 2 A-p 16^{I N K 4 a}$ is also more frequently observed among primary than secondary glioblastomas, whereas other alterations of this gene predominate in the latter tumors. ${ }^{6}$ Chromosome $9 \mathrm{p}$ deletions involving the $C D K N 2 A-p 16^{I N K 4 a}$ gene typically target other closely located genes, such as the methylthioadenosine phosphorylase (MTAP) gene, whose relevance in GBM remains to be established. $^{62}$

LOH of chromosome 10 is present in up to $70 \%$ of primary glioblastomas, ${ }^{1,63}$ suggesting the presence of several tumorsuppressor genes in this chromosome, which may be involved in GBM tumorigenesis. Three main chromosomal regions are commonly deleted: 10p14-15, 10q23-24 (PTEN), and 10q25-pter. Interestingly, PTEN gene mutations have been reported in approximately $25 \%$ of all glioblastomas, ${ }^{22}$ with such mutations being almost exclusively detected among primary glioblastoma ${ }^{1}$; by contrast, PTEN homozygous deletion occurs rarely. More than half of PTEN mutations result in the introduction of premature stop codons, leading to translation of truncated proteins. Alterations involving the $P T E N$ gene rarely occur in low-grade gliomas, whereas the frequency of inactivation of the PTEN gene increases in the more advanced stages of the disease (Figure 1B). Interestingly, primary GBMs frequently show loss of chromosome 10 in association with EGFR amplification, raising the possibility that the interaction between EGFR signaling and functional abrogation of relevant chromosome 10 suppressor genes may contribute to the aggressive features of GBM.

On the basis of the pilot project of the TCGA Consortium and other studies, additional genetic alterations have been identified in primary GBM, which include $N F 1$ mutation/ homozygous deletion (18\%) and PIK3RI (regulatory subunit 1 of phosphatidylinositol 3-kinase) mutations (10\%). ${ }^{24}$ In turn, mutation and/or amplification of the PIK3CA gene, which codes for the catalytic subunit $\alpha$ of the phosphatidylinositol-4,5-bisphosphate 3-kinase, is a rare event in both primary and secondary GBMs (approximately 5\% and approximately $13 \%$, respectively). ${ }^{64}$

In contrast to primary GBM, TP53 mutations at chromosome $17 \mathrm{p}$ are most frequently seen in secondary GBM, mainly involving codons 248 and 273 and G:C $\rightarrow$ A:T mutations at $\mathrm{CpG}$ (cytosine-phospho-guanine) sites. TP53 mutations in secondary GBM are already detectable at the early stages of the disease, ${ }^{1}$ and they seem to be an early event associated with malignant transformation in the pathway to secondary GBM (Figure 1B). Interestingly, methylation of the promoter of the MGMT DNA repair gene is also frequently associated with $\mathrm{G}: \mathrm{C} \rightarrow \mathrm{A}: \mathrm{T}$ mutations of the TP53 gene. ${ }^{3,65}$ In addition, isocitrate dehydrogenase $1(I D H 1)$ and $\mathrm{IDH} 2$ mutations have been identified recently, as early genetic alterations present in most low-grade gliomas, as well as in the pathway to secondary glioblastomas. However, they are rare among primary GBMs. ${ }^{7}$ In gliomas, $I D H 1 / 2$ mutations are associated with an increased DNA hypermethylation profile ${ }^{66}$; therefore, it is likely that $I D H 1 / 2$ mutations are involved in oncogenesis through inactivation of tumor-suppressor genes via hypermethylation of their promoters, which is facilitated by the mutated gene/protein. Gliomas with mutated $I D H I$ and $I D H 2$ have a better prognosis compared with gliomas with wild-type $I D H{ }^{8}$ Inactivation of the proapoptotic Harakiri $(H R K)$ gene, which encodes for a bcl2-interacting protein at $12 \mathrm{q} 24,{ }^{67}$ because of hypermethylation of its promoter, could play a critical role in the development and progression of secondary GBM via abrogation of apoptosis in tumors expressing wild-type TP53.

Partial LOH of chromosome 10q is also a frequent event in secondary glioblastomas. ${ }^{10} \mathrm{LOHs}$ of chromosome $13 \mathrm{q}$ (typically including the $R B$ locus), chromosome $19 \mathrm{q}$ (with a common deleted region at $19 \mathrm{q} 13.3),{ }^{11}$ and chromosome $22 \mathrm{q}$ (including the TIMP-3 putative tumor-suppressor gene at $22 \mathrm{q} 12.3)^{4}$ have been detected more frequently in secondary versus primary GBM. Less commonly than in primary GBMs, secondary GBMs also display amplification of the $P D G F R A$ and/or PDGFRB genes, potentially in association with overexpression of the PDGF ligand, yielding to an autocrine loop in GBM tumor cells. Table 1 summarizes all of the above described and other genetic alterations and altered gene/protein expression profiles associated with primary versus secondary GBM. ${ }^{12-20}$

\section{Genetic and Molecular Alterations of GBM with Clinical Impact}

In the past decades, several alterations reported in GBM have emerged as being of potential clinical relevance for more accurate diagnostic classification, prognostic stratification, and/or prediction of response to therapy in GBM. Among others, amplification of the EGFR gene, IDH1/IDH2 mutations, and hypermethylation of the promoter of the $\mathrm{O}(6)$ methylguanine-DNA methyltransferase (MGMT) gene have become particularly relevant from the clinical point of view, in addition to detection of codeletion of chromosomes $1 \mathrm{p}$ and 19q in low-grade gliomas. In turn, gene expression profiles (GEPs) are still not yet being generally used.

\section{EGFR Amplification and EGFR Genetic Variants}

EGFR is a transmembrane glycoprotein that acts as a TKR. Once bound to its ligand, EGFR becomes autophosphorylated and induces subsequent activation of signal transduction pathways involved in the regulation of cell proliferation, differentiation, and survival. Although present in normal 
cells, the EGFR gene is the most frequently overexpressed gene, mainly in primary GBM, ${ }^{1,22}$ and its alterations in gliomas are highly associated with high-grade malignancy. ${ }^{68}$ However, controversial results exist regarding the prognostic significance of EGFR amplification in GBM. Although some studies reported that EGFR amplification is associated with a poor prognosis and a shorter survival of GBM patients, ${ }^{69}$ others claim that such association with survival would not be significant or that it could even be associated with a better outcome. ${ }^{70}$ In turn, some reports have found a poor prognosis for GBM patients carrying amplification of the $E G F R$ gene among all age groups, whereas others have found $E G F R$ amplification to be a predictor for prolonged survival only among older patients. Such discrepant results could potentially be associated with the specific underlying genetic lesion targeting the EGFR gene. In this regard, the prognostic impact of EGFRVIII (the most common EGFR mutant variant, which leads to constitutive activation of EGFR in a ligandindependent way) has not been investigated as extensively as EGFR amplification. Despite this, controversial results have also emerged. Accordingly, the EGFRvIII variant has been found not to be related to patient outcome, ${ }^{71}$ to be associated with an unfavorable prognosis, ${ }^{72}$ or even to be a molecular predictor for prolonged overall survival among (conventionally) treated GBM patients. ${ }^{73}$ Some other polymorphic genetic variants of the EGFR gene (eg, the -191C/A polymorphism involving the promoter region of the gene) have also been associated with the prognosis of glioma patients, ${ }^{74}$ but its clinical value still deserves confirmation.

In addition, it has also been speculated that the EGFR status could contribute to predict response to EGFR-targeted therapies. In fact, several mono and multiple EGFR-targeted therapies have been developed and assayed in recent years, including antibodies and small-molecule inhibitors of EGFR. Among other agents, two small-molecule EGFR inhibitors (gefitinib and erlotinib) have been extensively tested, but the response to these drugs (eg, erlotinib as a single agent) did not seem to be effective. ${ }^{75}$ Other EGFR-directed therapies, such us RNA-based treatment approaches, ligand-toxin conjugates, and radioimmunoconjugates, are currently at various stages of evaluation for clinical purposes. ${ }^{33,76}$ In parallel, efforts are being made to increase the knowledge about the mechanisms underlying resistance to EGFR-targeted therapies and to clarify the clinical value of $E G F R$ amplification and its variants (eg, EGFRvIII) for prognostic stratification of GBM. $^{61}$

\section{IDH1/IDH2 Mutations}

IDHs catalyze the oxidative decarboxylation of isocitrate to $\alpha$-ketoglutarate and reduce $\mathrm{NAD}^{+}$and $\mathrm{NADP}^{+}$to NADH and NADPH, respectively. ${ }^{77}$ IDH1 is localized in the cytoplasm and the peroxisomes, whereas IDH2 is in the mitochondria, ${ }^{78}$ where they are involved in the tricarboxylic acid cycle, as well as in protection against oxidative stress. IDH1 participates in the lipid and glucose metabolism. ${ }^{79}$
Parsons et $\mathrm{al}^{80}$ revealed, by gene sequencing of $22 \mathrm{GBMs}$, the presence of recurrent $(12 \%)$ point mutations in the active site of $I D H I$, a gene that had never been linked to cancer before. Furthermore, it was found that other GBMs, which do not have IDHI mutations, may show mutation of the $I D H 2$ gene. ${ }^{8}$ IDHI (coded at chromosome 2q33) and IDH2 (coded at chromosome 15q26) mutations typically consist of monoallelic, somatic, and missense changes. Mutations of IDHI almost always affect the $R 132$ codon,${ }^{80}$ and $I D H 2$ mutations exclusively affect the $R 172$ and $R 140$ codons. ${ }^{8}$ Both $I D H I$ and $I D H 2$ mutations are more frequently detected among grade II to III gliomas and secondary glioblastoma (70\% to $75 \%$ ), whereas they are rare in primary glioblastoma $(5 \%){ }^{7,81}$ Interestingly, the occurrence of $I D H I$ mutations in diffuse gliomas is strongly associated with TP53 mutation and also del(1p)/del(19q), indicating that they may represent an early event. ${ }^{82}$ Both younger age and mutated TP53 have been reported to be associated with a better outcome among GBM patients. Noteworthy, IDHI mutations are present in a higher fraction of younger patients, who also carry a high frequency of TP53 mutations, all being typical features of secondary GBM. ${ }^{9,83}$ Other genetic associations that have been reported in gliomas include $I D H 1$ mutation and $M G M T$ promoter methylation, in the absence of chromosome 10 losses and EGFR amplification. ${ }^{84}$ Altogether, these associations might contribute to explain why $I D H 1 / I D H 2$ mutations have been found to be positive prognostic factors. ${ }^{9,84}$

Efforts are ongoing to better understand the role of $I D H I$ mutations in gliomagenesis. Initially, it was postulated that mutations could abrogate the function of the protein, leading to reduced synthesis of the $\alpha$-ketoglutarate metabolite, ${ }^{85}$ but striking new pieces of evidence have shown that IDH1 mutants also confer an enzymatic gain-of-function phenotype, associated with production of the alternative metabolite, 2-hydroxyglutarate; because 2-hydroxyglutarate may contribute to gliomagenesis, ${ }^{86}$ a new hypothesis has been raised about whether treatments that would reduce production of 2-hydroxyglutarate could be effective against gliomas with IDHI mutation.

\section{Hypermethylation of the MGMT Promoter}

The MGMT gene (coded at chromosome 10q26) is frequently silenced in GBM by promoter hypermethylation in association or not with monosomy 10/del(10q). Currently, this represents one of the most relevant prognostic factors in GBM and a potent predictor of response to treatment with alkylating agents. ${ }^{87}$ Accordingly, an association between methylation of the MGMT gene promoter and response to alkylating chemotherapy using nitrosourea compounds, temozolomide (TMZ), or a combination of both ${ }^{88}$ has been observed in GBM. Several alkylation sites have been described in the DNA, as targets for these cytotoxic compounds, the most frequent site being the O6-position of guanine. The use of alkylating chemotherapeutic drugs, such as TMZ, causes binding of an alkyl group to the O6-position 
of guanine, thereby inducing a DNA mismatch, DNA double-strand breakage, and ultimately apoptosis of proliferating cells. Thus, the MGMT protein counteracts the normally lethal effect of TMZ by repairing DNA damage. When a tumor has a hypermethylated MGMT promoter, transcription of the gene is blocked, leading to lack of MGMT mRNA and protein expression, while enhancing the cytotoxic effects of the alkylating drug(s).

Previous studies have shown that patients with hypermethylation of the $M G M T$ gene promoter may have longer survival rates when treated with both TMZ and radiotherapy (median survival at 2 and 5 years of $49 \%$ and $14 \%$, respectively) instead of radiotherapy alone (median survival at 2 and 5 years of $24 \%$ and $5 \%$, respectively). ${ }^{83,89,90}$ However, it has been recently reported that methylation of the MGMT promoter could also be predictive of response to radiotherapy and a longer survival in GBM, in the absence of adjuvant chemotherapy. ${ }^{91}$ Therefore, it remains unclear whether MGMT also plays a role in repairing radiotherapy-induced DNA damage, whether other DNA repair genes than MGMT are also silenced by promoter hypermethylation, or whether the survival advantage of such MGMT hypermethylated cases is better explained by other coexisting prognostically favorable genetic features frequently observed in low-grade oligodendrogliomas and secondary GBM, such as codeletion of chromosomes $1 \mathrm{p}$ and $19 \mathrm{q}^{92}$ and $I D H 1$ mutation. ${ }^{84}$

Despite its recognition as a favorable prognostic marker, $M G M T$ testing is still not widely used in the day-to-day laboratory routine of most centers; this is mainly due to the lack of technical standardization ${ }^{65,93}$ because of sample heterogeneity and lack of precise identification/validation of specific MGMT promoter regions predictive of patient response to therapy. In addition, several studies indicate that the pattern of expression of the MGMT protein is associated with neither the methylation status of the MGMT promoter nor the patient outcome, suggesting that other molecular mechanisms, in addition to $M G M T$ promoter methylation and $\operatorname{del}(10 \mathrm{q}) /$ monosomy 10 , may be involved. ${ }^{94}$

\section{GEP of GBM and Its Molecular/Genomic Subtypes}

In the past decade, efforts have been made to further define the impact of genetic/molecular alterations of GBM at the genomic level. Recent availability of high-throughput microarray-based assays allowed for genome-wide quantitative analysis of thousands of genes simultaneously, providing new insights into patterns of overexpressed and underexpressed genes potentially involved in malignant transformation and disease progression. Early GEP studies identified differentially expressed genes among histopathologically defined subtypes of gliomas (eg, GBM versus oligodendrogliomas, ${ }^{95}$ lowversus high-grade astrocytomas, ${ }^{95}$ primary versus secondary GBM,${ }^{96}$ or even GBM with versus without $E G F R$ amplification). ${ }^{95}$ Altogether, these results indicate that histopathological subtypes of gliomas, and also genetic subgroups of GBM, show unique GEP at the mRNA transcriptional level that may potentially be used to distinguish among them.

Despite this, discordant results between morphological and molecular tumor subtypes, as defined by GEP, have been also frequently observed among histologically ambiguous gliomas. In this regard, the potential diagnostic utility of GEP for the molecular classification of gliomas has been highlighted by Nutt et al, ${ }^{97}$ who identified two sets of genes significantly associated with classic GBM or anaplastic oligodendroglioma, and built a class prediction model that showed an accuracy of $86 \%$ in assigning diagnostically challenging samples. In another collaborative study, Parsons et $\mathrm{al}^{80}$ discovered a variety of genes that, at that time, were unknown to be altered in GBM (eg, recurrent mutations of the IDHI gene were detected in $12 \%$ of the cases).

In addition, several GEP studies have identified distinct molecular subtypes of gliomas with prognostic significance. Early studies by Freije et al $^{98}$ identified 595 differentially expressed genes that correlated with overall survival in 74 gliomas. Such molecular subtypes [hierarchical clustering (HC) $1 \mathrm{~A}, \mathrm{HC} 1 \mathrm{~B}, \mathrm{HC} 2 \mathrm{~A}$, and $\mathrm{HC} 2 \mathrm{~B}$ ] could be further segregated into two groups of patients with distinct survival (median overall survival of 4.8 and 0.6 years) through HC. Nutt et $\mathrm{al}^{97}$ showed that the prognostic impact of the survival cluster on the basis of tumor GEP was independent of patient age and histological grade. Interestingly, this study also showed that one subtype was enriched for genes involved in neurogenesis, whereas the poor survival subtypes were enriched for genes associated with cell proliferation and extracellular matrix/invasion, suggesting a more versus less differentiated phenotype for the two groups, respectively.

Later, Phillips et $\mathrm{al}^{99}$ subdivided GBM into three groups [eg, mesenchymal (MQ), proliferative (PF), and proneural $(\mathrm{PN})]$, according to the similarities observed between distinct tumoral GEP and both key stages in neurogenesis and known cell types. MQ, PF, and PN signatures were associated with those of neural stem cells, transit-amplifying cells, and immature neurons, respectively. The PN signature is typically overrepresented among less aggressive forms of high-grade gliomas, whereas the MQ and PF subtypes were enriched in more aggressive high-grade tumors; in addition, such classification also showed an association with clinical outcome. A subsequent meta-analysis on $267 \mathrm{GBMs}$, on the basis of previously published data together with new GEP data ${ }^{100}$ identified 377 differentially expressed genes, which classified GBM into four distinct subtypes by $\mathrm{HC}$ analyses: $\mathrm{HC} 1 \mathrm{~A} / \mathrm{PN}, \mathrm{HC} 2 \mathrm{~A} / \mathrm{PF}, \mathrm{HC} 2 \mathrm{~B} / \mathrm{MQ}$, and a fourth subtype with $\mathrm{HC} 2 \mathrm{~A} / \mathrm{HC} 2 \mathrm{~B}$ hybrid features, termed PF/MQ. Survival analysis confirmed the more favorable outcome of $\mathrm{HC} 1 \mathrm{~A} /$ PN GBM versus the other three subtypes. Moreover, younger GBM patients more frequently had PN GBM type tumors, which could contribute to explain their longer life expectancy and their better outcome.

Vital et $\mathrm{al}^{95}$ investigated the association between the GEP and both the cytogenetics and histopathology of 40 gliomas. 
Table 2 Classifications of GBM Proposed on the Basis of Different Profiles of Molecular and Genetic Alterations Identified and the Relationship Existing between the Different Subtypes Identified

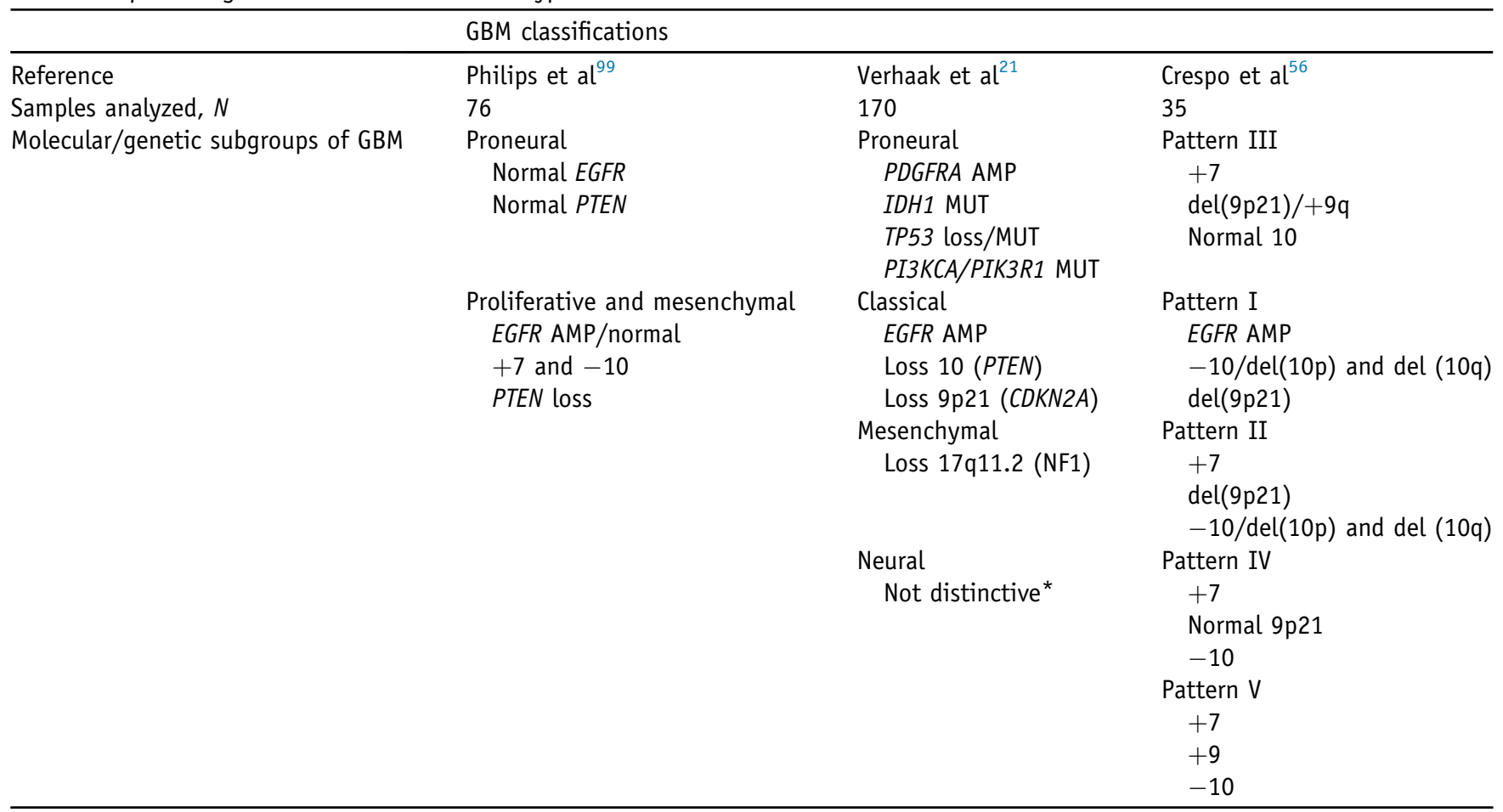

*Expression of neuron histological markers.

AMP, gene amplification; GBM, glioblastoma multiforme; MUT, gene mutation; NF1, neurofibromatosis type I.

Unsupervised and supervised analyses showed significantly different GEP in low- versus high-grade gliomas, the most discriminating genes including genes involved in the regulation of cell proliferation, apoptosis, DNA repair, and signal transduction. In turn, among GBM, three subgroups of tumors were identified according to their GEP, which were closely associated with the cytogenetic profile of their ancestral tumor cell clones: i) EGFR amplification, ii) isolated trisomy 7, and iii) more complex karyotypes. In this regard, we have also investigated the direct impact of cytogenetic alterations defined by copy number changes on the mRNA levels of the specific genes involved. ${ }^{62}$ In that study, we detected recurrent amplicons for chromosomes 7 (50\%), 12 (22\%), 1 (11\%), 4 (9\%), $11(4 \%)$, and 17 (4\%), whereas homozygous deletions involved chromosomes 9p21 (52\%) and 10q (22\%). Most genes that displayed a high correlation between DNA copy number alteration (CNA) and mRNA levels were coded in the amplified chromosomes. For some amplicons, the impact of DNA CNA on mRNA expression was restricted to a single gene (eg, EGFR at $7 \mathrm{p} 11.2$ ), whereas for others, it involved multiple genes (eg, 11 and 5 genes at 12q14.1-q15 and $4 \mathrm{q} 12$, respectively). Although homozygous del(9p21) and del(10q23.31) included multiple genes, association between these DNA CNAs and RNA expression was restricted to a few genes [eg, the MTAP gene in case of del(9p21)].

Until now, the most comprehensive and reliable analysis of genomic alterations in GBM has been conducted by the TCGA Consortium. Initially, the TCGA Consortium published mRNA expression data and DNA CNA data on approximately $206 \mathrm{GBMs}$; at the same time, $>600$ genes were also sequenced in a subgroup of $91 \mathrm{GBMs} .{ }^{24}$ Overall, three major signaling pathways were found to be consistently affected in many GBM tumors: the TKR-signaling pathway (88\%), the TP53 pathway (87\%), and the RB pathway (78\%); the genes involved in these pathways included the NFI tumor-suppressor gene and the PIK3RI gene, which had been previously reported to be altered in GBM. ${ }^{80}$ In a more recent multidimensional study including previous TCGA data, together with the patterns of somatic mutations, DNA CNA, and the tumor-associated GEP, an integrated molecular classification of GBM was proposed. ${ }^{21}$ This classification included four subtypes of GBM defined by the patterns of alteration of the EGFR, NF1, PDGFRA, and $I D H 1$ genes and the GEP: classic, MQ, PN, and neural (Table 2). These subtypes also differed in their response to treatment and overall survival. Classic GBM displayed a characteristic profile with high proliferation, frequently associated with high-level EGFR amplification, monosomy 10, and homozygous del(9p21.3) targeting the CDKN2A$p 16^{I N K 4 a}$ gene. The MQ GBMs were defined by overexpression of MQ (CHI3L1/YKL40 and MET) and astrocytic (CD44 and MERTK) markers, plus NF1 deletion or mutation (17q11.2). The PN GBMs presented with activation of both oligodendrocytic (PDGFRA, OLIG2, TCF3, and NKX2-2) and PN (SOX, DCX, DLL3, ASCL1, and TCF4) developmentassociated genes, and they were characterized by molecular 
alterations of TP53 and PDGFRA, as well as PIK3CA/ $P I K 3 R 1$ and IDHI mutations. Finally, neural GBM lacked a distinctive genetic profile and display gene expression signatures that are similar to those found in normal brain tissue, with expression of neuron markers such as NEFL, GABRA1, SYT1, and SLC12A5. Although in primary GBM, several molecular abnormalities (eg, EGFR, MTAP, and PDGFRA alterations) were strongly associated with specific GEPs (eg, EGFR and MTAP genetic alterations were associated with $\mathrm{PF}$, classic, and PN GBM, respectively), ${ }^{21,99,100}$ the association between the genes involved in secondary GBM and their potentially associated GEP still remains to be determined and requires further assessment.

\section{Conclusions}

Overall, GBMs carry numerous recurrent genetic alterations that translate into different cytogenetic and genomic profiles that are difficult to distinguish on histopathological grounds. Although further validation in larger series of GBM is still needed, current knowledge about the complex genome of GBM points to the existence of four major profiles: classic, MQ, PN, and neural GBM. Such genomic profiles of GBM reflect both different cytogenetic profiles, as well as unique GEPs associated with distinct patterns of alteration of intracellular signaling pathways, in addition to key stages in neurogenesis and features of distinct normal central nervous system cell types. Additional pieces of evidence also confirm that the relationship between DNA (eg, copy number) alteration and gene expression at the mRNA level is not always straightforward; distant genetic interactions and epigenetic changes also have a significant impact on the expression of specific genes. Selection of just the most commonly amplified and mutated genes as a therapeutic target may not be sufficient. In turn, identification of driver mutations using large-scale, next-generation sequencing or single-tumor cell sequencing, as well as genomic analyses within individual tumors, in combination with new proteomic strategies to identify aberrant cancer peptides may contribute to the identification of new drugs and antibody targets that may help in suppressing the disease and improving the management of GBM patients.

\section{References}

1. Ohgaki H, Dessen P, Jourde B, Horstmann S, Nishikawa T, Di Patre PL, Burkhard C, Schuler D, Probst-Hensch NM, Maiorka PC, Baeza N, Pisani P, Yonekawa Y, Yasargil MG, Lutolf UM, Kleihues P: Genetic pathways to glioblastoma: a population-based study. Cancer Res 2004, 64:6892-6899

2. Brennan CW, Verhaak RG, McKenna A, Campos B, Noushmehr H, Salama SR, et al; TCGA Research Network: The somatic genomic landscape of glioblastoma. Cell 2013, 155:462-477

3. Nakamura M, Watanabe T, Yonekawa Y, Kleihues P, Ohgaki H Promoter methylation of the DNA repair gene MGMT in astrocytomas is frequently associated with $\mathrm{G}$ : $\mathrm{C}->\mathrm{A}$ : $\mathrm{t}$ mutations of the TP53 tumor suppressor gene. Carcinogenesis 2001, 22:1715-1719
4. Nakamura M, Ishida E, Shimada K, Kishi M, Nakase H, Sakaki T, Konishi N: Frequent LOH on 22q12.3 and TIMP-3 inactivation occur in the progression to secondary glioblastomas. Lab Invest 2005, 85: $165-175$

5. Nakamura M, Yonekawa Y, Kleihues P, Ohgaki H: Promoter hypermethylation of the RB1 gene in glioblastomas. Lab Invest 2001, 81:77-82

6. Nakamura M, Watanabe T, Klangby U, Asker C, Wiman K, Yonekawa Y, Kleihues P, Ohgaki H: p14ARF deletion and methylation in genetic pathways to glioblastomas. Brain Pathol 2001, 11: $159-168$

7. Jiao Y, Killela PJ, Reitman ZJ, Rasheed AB, Heaphy CM, de Wilde RF, Rodriguez FJ, Rosemberg S, Oba-Shinjo SM, Nagahashi Marie SK, Bettegowda C, Agrawal N, Lipp E, Pirozzi C, Lopez G, He Y, Friedman H, Friedman AH, Riggins GJ, Holdhoff M, Burger P, McLendon R, Bigner DD, Vogelstein B, Meeker AK, Kinzler KW, Papadopoulos N, Diaz LA, Yan H: Frequent ATRX, CIC, FUBP1 and IDH1 mutations refine the classification of malignant gliomas. Oncotarget 2012, 3:709-722

8. Yan H, Parsons DW, Jin G, McLendon R, Rasheed BA, Yuan W, Kos I, Batinic-Haberle I, Jones S, Riggins GJ, Friedman H, Friedman A, Reardon D, Herndon J, Kinzler KW, Velculescu VE, Vogelstein B, Bigner DD: IDH1 and IDH2 mutations in gliomas. N Engl J Med 2009, 360:765-773

9. Nobusawa S, Watanabe T, Kleihues P, Ohgaki H: IDH1 mutations as molecular signature and predictive factor of secondary glioblastomas. Clin Cancer Res 2009, 15:6002-6007

10. Fujisawa H, Reis RM, Nakamura M, Colella S, Yonekawa Y, Kleihues P, Ohgaki H: Loss of heterozygosity on chromosome 10 is more extensive in primary (de novo) than in secondary glioblastomas. Lab Invest 2000, 80:65-72

11. Nakamura M, Yang F, Fujisawa H, Yonekawa $Y$, Kleihues $P$, Ohgaki H: Loss of heterozygosity on chromosome 19 in secondary glioblastomas. J Neuropathol Exp Neurol 2000, 59:539-543

12. Tohma Y, Gratas C, Van Meir EG, Desbaillets I, Tenan M, Tachibana O, Kleihues P, Ohgaki H: Necrogenesis and Fas/APO-1 (CD95) expression in primary (de novo) and secondary glioblastomas. J Neuropathol Exp Neurol 1998, 57:239-245

13. Xie D, Zeng YX, Wang HJ, Wen JM, Tao Y, Sham JS, Guan XY: Expression of cytoplasmic and nuclear Survivin in primary and secondary human glioblastoma. Br J Cancer 2006, 94:108-114

14. Choe G, Park JK, Jouben-Steele L, Kremen TJ, Liau LM, Vinters HV, Cloughesy TF, Mischel PS: Active matrix metalloproteinase 9 expression is associated with primary glioblastoma subtype. Clin Cancer Res 2002, 8:2894-2901

15. Watanabe K, Tachibana O, Sata K, Yonekawa Y, Kleihues P, Ohgaki H: Overexpression of the EGF receptor and p53 mutations are mutually exclusive in the evolution of primary and secondary glioblastomas. Brain Pathol 1996, 6:217-223

16. Furuta M, Weil RJ, Vortmeyer AO, Huang S, Lei J, Huang TN, Lee YS, Bhowmick DA, Lubensky IA, Oldfield EH, Zhuang Z: Protein patterns and proteins that identify subtypes of glioblastoma multiforme. Oncogene 2004, 23:6806-6814

17. Biernat W, Kleihues P, Yonekawa Y, Ohgaki H: Amplification and overexpression of MDM2 in primary (de novo) glioblastomas. J Neuropathol Exp Neurol 1997, 56:180-185

18. Karcher S, Steiner HH, Ahmadi R, Zoubaa S, Vasvari G, Bauer H, Unterberg A, Herold-Mende C: Different angiogenic phenotypes in primary and secondary glioblastomas. Int J Cancer 2006, 118:2182-2189

19. Godard S, Getz G, Delorenzi M, Farmer P, Kobayashi H, Desbaillets I, Nozaki M, Diserens AC, Hamou MF, Dietrich PY, Regli L, Janzer RC, Bucher P, Stupp R, de Tribolet N, Domany E, Hegi ME: Classification of human astrocytic gliomas on the basis of gene expression: a correlated group of genes with angiogenic activity emerges as a strong predictor of subtypes. Cancer Res 2003, 63:6613-6625

20. Somasundaram K, Reddy SP, Vinnakota K, Britto R, Subbarayan M, Nambiar S, Hebbar A, Samuel C, Shetty M, Sreepathi HK, 
Santosh V, Hegde AS, Hegde S, Kondaiah P, Rao MR: Upregulation of ASCL1 and inhibition of Notch signaling pathway characterize progressive astrocytoma. Oncogene 2005, 24:7073-7083

21. Verhaak RG, Hoadley KA, Purdom E, Wang V, Qi Y, Wilkerson MD, Miller CR, Ding L, Golub T, Mesirov JP, Alexe G, Lawrence M, O'Kelly M, Tamayo P, Weir BA, Gabriel S, Winckler W, Gupta S, Jakkula L, Feiler HS, Hodgson JG, James CD, Sarkaria JN, Brennan C, Kahn A, Spellman PT, Wilson RK, Speed TP, Gray JW, Meyerson M, Getz G, Perou CM, Hayes DN: Integrated genomic analysis identifies clinically relevant subtypes of glioblastoma characterized by abnormalities in PDGFRA, IDH1, EGFR, and NF1. Cancer Cell 2010, 17:98-110

22. Ohgaki H, Kleihues P: Genetic pathways to primary and secondary glioblastoma. Am J Pathol 2007, 170:1445-1453

23. Mao H, Lebrun DG, Yang J, Zhu VF, Li M: Deregulated signaling pathways in glioblastoma multiforme: molecular mechanisms and therapeutic targets. Cancer Invest 2012, 30:48-56

24. The Cancer Genome Atlas (TCGA) Research Network: Comprehensive genomic characterization defines human glioblastoma genes and core pathways. Nature 2008, 455:1061-1068

25. Dunn GP, Rinne ML, Wykosky J, Genovese G, Quayle SN, Dunn IF, Agarwalla PK, Chheda MG, Campos B, Wang A, Brennan C, Ligon KL, Furnari F, Cavenee WK, Depinho RA, Chin L, Hahn WC: Emerging insights into the molecular and cellular basis of glioblastoma. Genes Dev 2012, 26:756-784

26. Nakada M, Kita D, Watanabe T, Hayashi Y, Teng L, Pyko IV, Hamada J: Aberrant signaling pathways in glioma. Cancers (Basel) 2011, 3:3242-3278

27. Zheng Y, McFarland BC, Drygin D, Yu H, Bellis SL, Kim H, Bredel M, Benveniste EN: Targeting protein kinase CK2 suppresses prosurvival signaling pathways and growth of glioblastoma. Clin Cancer Res 2013, 19:6484-6494

28. Fredriksson L, Li H, Eriksson U: The PDGF family: four gene products form five dimeric isoforms. Cytokine Growth Factor Rev 2004, 15:197-204

29. Alentorn A, Marie Y, Carpentier C, Boisselier B, Giry M, Labussiére M, Mokhtari K, Hoang-Xuan K, Sanson M, Delattre JY, Idbaih A: Prevalence clinico-pathological value, and co-occurrence of PDGFRA abnormalities in diffuse gliomas. Neuro Oncol 2012, 14:1393-1403

30. Rheinbay E, Suva ML, Gillespie SM, Wakimoto H, Patel AP, Shahid M, Oksuz O, Rabkin SD, Martuza RL, Rivera MN, Louis DN, Kasif S, Chi AS, Bernstein BE: An aberrant transcription factor network essential for Wnt signaling and stem cell maintenance in glioblastoma. Cell Rep 2013, 3:1567-1579

31. Nicholas MK, Lukas RV, Jafri NF, Faoro L, Salgia R: Epidermal growth factor receptor-mediated signal transduction in the development and therapy of gliomas. Clin Cancer Res 2006, 12:7261-7270

32. Huang PH, Xu AM, White FM: Oncogenic EGFR signaling networks in glioma. Sci Signal 2009, 2:re6

33. Hatanpaa KJ, Burma S, Zhao D, Habib AA: Epidermal growth factor receptor in glioma: signal transduction, neuropathology, imaging, and radioresistance. Neoplasia 2010, 12:675-684

34. Patil CG, Nuno M, Elramsisy A, Mukherjee D, Carico C, Dantis J, Hu J, Yu JS, Fan X, Black KL, Bannykh SI: High levels of phosphorylated MAP kinase are associated with poor survival among patients with glioblastoma during the temozolomide era. Neuro Oncol 2013, 15:104-111

35. Downward J: Targeting RAS signalling pathways in cancer therapy. Nat Rev Cancer 2003, 3:11-22

36. Rajasekhar VK, Viale A, Socci ND, Wiedmann M, Hu X, Holland EC: Oncogenic Ras and Akt signaling contribute to glioblastoma formation by differential recruitment of existing mRNAs to polysomes. Mol Cell 2003, 12:889-901

37. Furnari FB, Fenton T, Bachoo RM, Mukasa A, Stommel JM, Stegh A, Hahn WC, Ligon KL, Louis DN, Brennan C, Chin L, DePinho RA, Cavenee WK: Malignant astrocytic glioma: genetics, biology, and paths to treatment. Genes Dev 2007, 21:2683-2710
38. Koul D: PTEN signaling pathways in glioblastoma. Cancer Biol Ther 2008, 7:1321-1325

39. Vogt PK: PI 3-kinase, mTOR, protein synthesis and cancer. Trends Mol Med 2001, 7:482-484

40. Fan X, Aalto Y, Sanko SG, Knuutila S, Klatzmann D, Castresana JS: Genetic profile, PTEN mutation and therapeutic role of PTEN in glioblastomas. Int J Oncol 2002, 21:1141-1150

41. Knudsen ES, Wang JY: Targeting the RB-pathway in cancer therapy. Clin Cancer Res 2010, 16:1094-1099

42. Matheu A, Maraver A, Serrano M: The Arf/p53 pathway in cancer and aging. Cancer Res 2008, 68:6031-6034

43. Shangary S, Wang S: Small-molecule inhibitors of the MDM2-p53 protein-protein interaction to reactivate p53 function: a novel approach for cancer therapy. Annu Rev Pharmacol Toxicol 2009, 49: 223-241

44. Grzmil M, Hemmings BA: Deregulated signalling networks in human brain tumours. Biochim Biophys Acta 2010, 1804:476-483

45. Dasari VR, Kaur K, Velpula KK, Gujrati M, Fassett D, Klopfenstein JD, Dinh DH, Rao JS: Upregulation of PTEN in glioma cells by cord blood mesenchymal stem cells inhibits migration via downregulation of the PI3K/Akt pathway. PLoS One 2010, 5:e10350

46. Van Meir EG, Hadjipanayis CG, Norden AD, Shu HK, Wen PY, Olson JJ: Exciting new advances in neuro-oncology: the avenue to a cure for malignant glioma. CA Cancer J Clin 2010, 60:166-193

47. Meletis K, Wirta V, Hede SM, Nister M, Lundeberg J, Frisen J: p53 Suppresses the self-renewal of adult neural stem cells. Development 2006, 133:363-369

48. Zawlik I, Kita D, Vaccarella S, Mittelbronn M, Franceschi S, Ohgaki H: Common polymorphisms in the MDM2 and TP53 genes and the relationship between TP53 mutations and patient outcomes in glioblastomas. Brain Pathol 2009, 19:188-194

49. Linares LK, Hengstermann A, Ciechanover A, Muller S, Scheffner M: HdmX stimulates Hdm2-mediated ubiquitination and degradation of p53. Proc Natl Acad Sci U S A 2003, 100:12009-12014

50. Jones PA, Baylin SB: The epigenomics of cancer. Cell 2007, 128: 683-692

51. Kloosterhof NK, de Rooi JJ, Kros M, Eilers PH, Sillevis Smitt PA, van den Bent MJ, French PJ: Molecular subtypes of glioma identified by genome-wide methylation profiling. Genes Chromosomes Cancer 2013, 52:665-674

52. Horiguchi K, Tomizawa Y, Tosaka M, Ishiuchi S, Kurihara H, Mori M, Saito N: Epigenetic inactivation of RASSF1A candidate tumor suppressor gene at 3p21.3 in brain tumors. Oncogene 2003, 22: $7862-7865$

53. Stone AR, Bobo W, Brat DJ, Devi NS, Van Meir EG, Vertino PM: Aberrant methylation and down-regulation of TMS1/ASC in human glioblastoma. Am J Pathol 2004, 165:1151-1161

54. Martinez R, Schackert G, Esteller M: Hypermethylation of the proapoptotic gene TMS1/ASC: prognostic importance in glioblastoma multiforme. J Neurooncol 2007, 82:133-139

55. Mellai M, Piazzi A, Caldera V, Annovazzi L, Monzeglio O, Senetta R, Cassoni P, Schiffer D: Promoter hypermethylation of the EMP3 gene in a series of 229 human gliomas. Biomed Res Int 2013, 2013:756302

56. Crespo I, Vital AL, Nieto AB, Rebelo O, Tao H, Lopes MC, Oliveira CR, French PJ, Orfao A, Tabernero MD: Detailed characterization of alterations of chromosomes 7, 9, and 10 in glioblastomas as assessed by single-nucleotide polymorphism arrays. J Mol Diagn 2011, 13:634-647

57. Vital AL, Tabernero MD, Crespo I, Rebelo O, Tao H, Gomes F, Lopes MC, Orfao A: Intratumoral patterns of clonal evolution in gliomas. Neurogenetics 2010, 11:227-239

58. Appin CL, Brat DJ: Molecular genetics of gliomas. Cancer J 2014, 20:66-72

59. Nonoguchi N, Ohta T, Oh JE, Kim YH, Kleihues P, Ohgaki H: TERT promoter mutations in primary and secondary glioblastomas. Acta Neuropathol 2013, 126:931-937 
60. Arita H, Narita Y, Fukushima S, Tateishi K, Matsushita Y, Yoshida A, Miyakita Y, Ohno M, Collins VP, Kawahara N, Shibui S, Ichimura $\mathrm{K}$ : Upregulating mutations in the TERT promoter commonly occur in adult malignant gliomas and are strongly associated with total 1p19q loss. Acta Neuropathol 2013, 126:267-276

61. Gan HK, Cvrljevic AN, Johns TG: The epidermal growth factor receptor variant III (EGFRvIII): where wild things are altered. FEBS J 2013, 280:5350-5370

62. Crespo I, Tao H, Nieto AB, Rebelo O, Domingues P, Vital AL, Patino Mdel C, Barbosa M, Lopes MC, Oliveira CR, Orfao A, Tabernero MD: Amplified and homozygously deleted genes in glioblastoma: impact on gene expression levels. PLoS One 2012, 7:e46088

63. Carico C, Nuno M, Mukherjee D, Elramsisy A, Dantis J, Hu J, Rudnick J, Yu JS, Black KL, Bannykh SI, Patil CG: Loss of PTEN is not associated with poor survival in newly diagnosed glioblastoma patients of the temozolomide era. PLoS One 2012, 7:e33684

64. Kita D, Yonekawa Y, Weller M, Ohgaki H: PIK3CA alterations in primary (de novo) and secondary glioblastomas. Acta Neuropathol 2007, 113:295-302

65. Kitange GJ, Carlson BL, Schroeder MA, Grogan PT, Lamont JD, Decker PA, Wu W, James CD, Sarkaria JN: Induction of MGMT expression is associated with temozolomide resistance in glioblastoma xenografts. Neuro Oncol 2009, 11:281-291

66. Christensen BC, Smith AA, Zheng S, Koestler DC, Houseman EA, Marsit CJ, Wiemels JL, Nelson HH, Karagas MR, Wrensch MR, Kelsey KT, Wiencke JK: DNA methylation, isocitrate dehydrogenase mutation, and survival in glioma. J Natl Cancer Inst 2011, 103:143-153

67. Inohara N, Ding L, Chen S, Nunez G: Harakiri, a novel regulator of cell death, encodes a protein that activates apoptosis and interacts selectively with survival-promoting proteins $\mathrm{Bcl}-2$ and $\mathrm{Bcl}-\mathrm{X}(\mathrm{L})$. EMBO J 1997, 16:1686-1694

68. Jeuken J, Sijben A, Alenda C, Rijntjes J, Dekkers M, BootsSprenger S, McLendon R, Wesseling P: Robust detection of EGFR copy number changes and EGFR variant III: technical aspects and relevance for glioma diagnostics. Brain Pathol 2009, 19:661-671

69. Murat A, Migliavacca E, Gorlia T, Lambiv WL, Shay T, Hamou MF, de Tribolet N, Regli L, Wick W, Kouwenhoven MC, Hainfellner JA, Heppner FL, Dietrich PY, Zimmer Y, Cairncross JG, Janzer RC, Domany E, Delorenzi M, Stupp R, Hegi ME: Stem cell-related "selfrenewal" signature and high epidermal growth factor receptor expression associated with resistance to concomitant chemoradiotherapy in glioblastoma. J Clin Oncol 2008, 26:3015-3024

70. Benito R, Gil-Benso R, Quilis V, Perez M, Gregori-Romero M, Roldan P, Gonzalez-Darder J, Cerda-Nicolas M, Lopez-Gines C: Primary glioblastomas with and without EGFR amplification: relationship to genetic alterations and clinicopathological features. Neuropathology 2010, 30:392-400

71. Heimberger AB, Hlatky R, Suki D, Yang D, Weinberg J, Gilbert M, Sawaya R, Aldape K: Prognostic effect of epidermal growth factor receptor and EGFRvIII in glioblastoma multiforme patients. Clin Cancer Res 2005, 11:1462-1466

72. Pelloski CE, Ballman KV, Furth AF, Zhang L, Lin E, Sulman EP, Bhat K, McDonald JM, Yung WK, Colman H, Woo SY, Heimberger AB, Suki D, Prados MD, Chang SM, Barker FG 2nd, Buckner JC, James CD, Aldape K: Epidermal growth factor receptor variant III status defines clinically distinct subtypes of glioblastoma. J Clin Oncol 2007, 25:2288-2294

73. Montano N, Cenci T, Martini M, D’Alessandris QG, Pelacchi F, Ricci-Vitiani L, Maira G, De Maria R, Larocca LM, Pallini R: Expression of EGFRvIII in glioblastoma: prognostic significance revisited. Neoplasia 2011, 13:1113-1121

74. Costa BM, Viana-Pereira M, Fernandes R, Costa S, Linhares P, Vaz R, Pinheiro C, Lima J, Soares P, Silva A, Pardal F, Amorim J, Nabico R, Almeida R, Alegria C, Pires MM, Carvalho E, Oliveira P, Lopes JM, Reis RM: Impact of EGFR genetic variants on glioma risk and patient outcome. Cancer Epidemiol Biomarkers Prev 2011, 20: $2610-2617$
75. van den Bent MJ, Brandes AA, Rampling R, Kouwenhoven MC, Kros JM, Carpentier AF, Clement PM, Frenay M, Campone M, Baurain JF, Armand JP, Taphoorn MJ, Tosoni A, Kletzl H, Klughammer B, Lacombe D, Gorlia T: Randomized phase II trial of erlotinib versus temozolomide or carmustine in recurrent glioblastoma: EORTC brain tumor group study 26034. J Clin Oncol 2009, 27:1268-1274

76. Paul I, Bhattacharya S, Chatterjee A, Ghosh MK: Current understanding on EGFR and Wnt/beta-catenin signaling in glioma and their possible crosstalk. Genes Cancer 2013, 4:427-446

77. Xu X, Zhao J, Xu Z, Peng B, Huang Q, Arnold E, Ding J: Structures of human cytosolic NADP-dependent isocitrate dehydrogenase reveal a novel self-regulatory mechanism of activity. J Biol Chem 2004 279:33946-33957

78. Reitman ZJ, Yan H: Isocitrate dehydrogenase 1 and 2 mutations in cancer: alterations at a crossroads of cellular metabolism. J Natl Cancer Inst 2010, 102:932-941

79. Joseph JW, Jensen MV, Ilkayeva O, Palmieri F, Alarcon C, Rhodes CJ, Newgard CB: The mitochondrial citrate/isocitrate carrier plays a regulatory role in glucose-stimulated insulin secretion. J Biol Chem 2006, 281:35624-35632

80. Parsons DW, Jones S, Zhang X, Lin JC, Leary RJ, Angenendt P, Mankoo P, Carter H, Siu IM, Gallia GL, Olivi A, McLendon R, Rasheed BA, Keir S, Nikolskaya T, Nikolsky Y, Busam DA, Tekleab H, Diaz LA Jr, Hartigan J, Smith DR, Strausberg RL, Marie SK, Shinjo SM, Yan H, Riggins GJ, Bigner DD, Karchin R, Papadopoulos N, Parmigiani G, Vogelstein B, Velculescu VE, Kinzler KW: An integrated genomic analysis of human glioblastoma multiforme. Science 2008, 321:1807-1812

81. Kloosterhof NK, Bralten LB, Dubbink HJ, French PJ, van den Bent MJ: Isocitrate dehydrogenase-1 mutations: a fundamentally new understanding of diffuse glioma? Lancet Oncol 2011, 12:83-91

82. Watanabe T, Nobusawa S, Kleihues P, Ohgaki H: IDH1 mutations are early events in the development of astrocytomas and oligodendrogliomas. Am J Pathol 2009, 174:1149-1153

83. Weller M, Felsberg J, Hartmann C, Berger H, Steinbach JP, Schramm J, Westphal M, Schackert G, Simon M, Tonn JC, Heese O, Krex D, Nikkhah G, Pietsch T, Wiestler O, Reifenberger G, von Deimling A, Loeffler M: Molecular predictors of progression-free and overall survival in patients with newly diagnosed glioblastoma: a prospective translational study of the German Glioma Network. J Clin Oncol 2009, 27:5743-5750

84. Sanson M, Marie Y, Paris S, Idbaih A, Laffaire J, Ducray F, El Hallani S, Boisselier B, Mokhtari K, Hoang-Xuan K, Delattre JY: Isocitrate dehydrogenase 1 codon 132 mutation is an important prognostic biomarker in gliomas. J Clin Oncol 2009, 27:4150-4154

85. Zhao S, Lin Y, Xu W, Jiang W, Zha Z, Wang P, Yu W, Li Z, Gong L, Peng Y, Ding J, Lei Q, Guan KL, Xiong Y: Glioma-derived mutations in IDH1 dominantly inhibit IDH1 catalytic activity and induce HIF-1alpha. Science 2009, 324:261-265

86. Dang L, White DW, Gross S, Bennett BD, Bittinger MA, Driggers EM, Fantin VR, Jang HG, Jin S, Keenan MC, Marks KM, Prins RM, Ward PS, Yen KE, Liau LM, Rabinowitz JD, Cantley LC, Thompson CB, Vander Heiden MG, Su SM: Cancer-associated IDH1 mutations produce 2-hydroxyglutarate. Nature 2009, 462:739-744

87. Zawlik I, Vaccarella S, Kita D, Mittelbronn M, Franceschi S, Ohgaki H: Promoter methylation and polymorphisms of the MGMT gene in glioblastomas: a population-based study. Neuroepidemiology $2009,32: 21-29$

88. Herrlinger U, Rieger J, Koch D, Loeser S, Blaschke B, Kortmann RD, Steinbach JP, Hundsberger T, Wick W, Meyermann R, Tan TC, Sommer C, Bamberg M, Reifenberger G, Weller M: Phase II trial of lomustine plus temozolomide chemotherapy in addition to radiotherapy in newly diagnosed glioblastoma: UKT-03. J Clin Oncol 2006, 24: 4412-4417

89. Stupp R, Hegi ME, Mason WP, van den Bent MJ, Taphoorn MJ, Janzer RC, Ludwin SK, Allgeier A, Fisher B, Belanger K, Hau P, 
Brandes AA, Gijtenbeek J, Marosi C, Vecht CJ, Mokhtari K, Wesseling P, Villa S, Eisenhauer E, Gorlia T, Weller M, Lacombe D, Cairncross JG, Mirimanoff RO: Effects of radiotherapy with concomitant and adjuvant temozolomide versus radiotherapy alone on survival in glioblastoma in a randomised phase III study: 5-year analysis of the EORTC-NCIC trial. Lancet Oncol 2009, 10:459-466

90. Linz U: Commentary on Effects of radiotherapy with concomitant and adjuvant temozolomide versus radiotherapy alone on survival in glioblastoma in a randomised phase III study: 5-year analysis of the EORTC-NCIC trial (Lancet Oncol. 2009;10:459-466). Cancer 2010, 116:1844-1846

91. Rivera AL, Pelloski CE, Gilbert MR, Colman H, De La Cruz C, Sulman EP, Bekele BN, Aldape KD: MGMT promoter methylation is predictive of response to radiotherapy and prognostic in the absence of adjuvant alkylating chemotherapy for glioblastoma. Neuro Oncol 2010, 12:116-121

92. Weller M, Berger H, Hartmann C, Schramm J, Westphal M, Simon M, Goldbrunner R, Krex D, Steinbach JP, Ostertag CB, Loeffler M, Pietsch T, von Deimling A: Combined 1p/19q loss in oligodendroglial tumors: predictive or prognostic biomarker? Clin Cancer Res 2007, 13:6933-6937

93. Weller M, Stupp R, Reifenberger G, Brandes AA, van den Bent MJ, Wick W, Hegi ME: MGMT promoter methylation in malignant gliomas: ready for personalized medicine? Nat Rev Neurol 2010, 6:39-51

94. Fan CH, Liu WL, Cao H, Wen C, Chen L, Jiang G: O6-methylguanine DNA methyltransferase as a promising target for the treatment of temozolomide-resistant gliomas. Cell Death Dis 2013, 4:e876
95. Vital AL, Tabernero MD, Castrillo A, Rebelo O, Tao H, Gomes F, Nieto AB, Resende Oliveira C, Lopes MC, Orfao A: Gene expression profiles of human glioblastomas are associated with both tumor cytogenetics and histopathology. Neuro Oncol 2010, 12:991-1003

96. Tso CL, Freije WA, Day A, Chen Z, Merriman B, Perlina A, Lee Y, Dia EQ, Yoshimoto K, Mischel PS, Liau LM, Cloughesy TF, Nelson SF: Distinct transcription profiles of primary and secondary glioblastoma subgroups. Cancer Res 2006, 66:159-167

97. Nutt CL, Mani DR, Betensky RA, Tamayo P, Cairncross JG, Ladd C, Pohl U, Hartmann C, McLaughlin ME, Batchelor TT, Black PM, von Deimling A, Pomeroy SL, Golub TR, Louis DN: Gene expressionbased classification of malignant gliomas correlates better with survival than histological classification. Cancer Res 2003, 63: $1602-1607$

98. Freije WA, Castro-Vargas FE, Fang Z, Horvath S, Cloughesy T, Liau LM, Mischel PS, Nelson SF: Gene expression profiling of gliomas strongly predicts survival. Cancer Res 2004, 64:6503-6510

99. Phillips HS, Kharbanda S, Chen R, Forrest WF, Soriano RH, Wu TD, Misra A, Nigro JM, Colman H, Soroceanu L, Williams PM, Modrusan Z, Feuerstein BG, Aldape K: Molecular subclasses of highgrade glioma predict prognosis, delineate a pattern of disease progression, and resemble stages in neurogenesis. Cancer Cell 2006, 9: $157-173$

100. Lee Y, Scheck AC, Cloughesy TF, Lai A, Dong J, Farooqi HK, Liau LM, Horvath S, Mischel PS, Nelson SF: Gene expression analysis of glioblastomas identifies the major molecular basis for the prognostic benefit of younger age. BMC Med Genomics 2008, 1:52 